\title{
Hedging functions of extraposed that-clauses in English and declarative subject $d a$-clauses in Croatian academic writing
}

\author{
Mirna Varga \\ University of Osijek, Croatia
}

\begin{abstract}
In academic writing stance is often conveyed by means of extraposed that-clauses (It is possible that the results were misinterpreted.). The impersonal form of a matrix predicate allows writers to express attitudes without assuming responsibility for the claim, which renders extraposition particularly convenient for hedging (Biber et al., 1999). The equivalent clause type in Croatian refers to declarative subject da-clauses (Moguće je da su rezultati krivo protumačeni.). The study examines the hedging potential of the target clauses in research articles in English and Croatian. Raising awareness of the way hedged stance is conveyed in cross-cultural academic writing may provide important implications for academic writing instruction particularly in a nonnative English context.
\end{abstract}

Keywords: extraposed that-clauses; declarative subject $d a$-clauses; hedging; English; Croatian.

\section{Introduction}

Contemporary research on academic discourse rests upon the premise that it is a form of social practice and as such inherently interactive (Hyland, 2004). By examining the concepts, such as hedging (Hyland, 1998), metadiscourse (Hyland, 2005), stance (Biber, 2006), etc., research has illuminated how academics use language to build their arguments, express viewpoints, engage with previous research, evaluate the content with an appropriate level of certainty or doubt, etc. to create a text that readers will find convincing and eventually accredit as a valid contribution to the existing disciplinary knowledge (Hyland, 1998). One of the central pragmatic phenomena underlying the interactive nature of academic discourse is hedging, broadly defined as a rhetorical strategy used to decrease the strength of one's claims (Hyland, 1998). In academic discourse, hedging is concerned with express- 
ing possibilities, tentative judgments, and speculations rather than categorical and factual statements. Though claims may be mitigated in multiple ways, hedging is typically associated with the use of modality devices (e.g. may, possible, perhaps, likelihood) (Hyland, 1998). In terms of syntax, hedged stance can be expressed by means of that-complement clauses (e.g. We hypothesize that...), in particular extraposed that-clauses (e.g. It is possible that...) (Hyland \& Tse, 2005). The latter are preceded by a matrix it-clause which allows writers to express stance towards the content of the complement clause without revealing the source(s) of the claim (Hewings \& Hewings, 2002). A congruent syntactic pattern in Croatian is a complement $d a$-clause (Cro. kompletiona, dopumbena rečenica), as in e.g. Pretpostavljamo da...'We hypothesize that...,' broadly defined as a dependent clause in which a matrix clause subjectively qualifies the content of the complement clause (Pranjković, 2001). An equivalent clause type to the extraposed that-clause refers to a declarative subject clause (Cro. izrična subjektna rečenica), which consists of a dependent clause controlled by the conjunction $d a$ and a matrix clause with an impersonal structure, such as an adverbial (e.g. Moguće je da...'It is possible that...') (Silić \& Pranjković, 2005). Extraposed clauses are relatively frequently employed for expressing various attitudinal meanings in academic prose, such as (un)certainty, necessity, affect, etc. (Biber et al., 1999). Likewise, Silić (2008) maintains that impersonal structures of matrix predicates of $d a$-complement clauses are commonly used in academic writing in Croatian.

By taking a cross-linguistic perspective, the primary focus of the current study is to explore how the given syntactic patterns are used as hedges in research article writing in English and Croatian. Though previous research has examined the pragmatic functions of that-complement clauses (including extraposition) in expert (Hyland \& Tse, 2005) and student writing in English (Hewings \& Hewings, 2001), the present study aims to enrich the former by providing a more comprehensive account of the hedging potential of extraposed that-clauses in research articles in psychology. More specifically, it examines the lexical choices of the matrix predicates, their distribution as well as hedging functions across the IMRAD structure. The study is extended by accounting for the hedging functions of the declarative subject clauses controlled by the conjunction $d a$ in the comparable corpus of research articles in Croatian, which to the best of the author's knowledge has not been previously examined. By providing a corpus-based, cross-linguistic analysis of the target patterns, the present study aims to deepen our knowledge and raise awareness of the way hedged stance is conveyed in the disciplinary writing in each language. This is particularly important for the linguistic account of the Croatian academic writing, which has been, understandably, significantly less researched than the English. At the same time, it aims to provide important evidence-based insights into the patterns of cross- 
linguistic similarities and differences in the distribution and the hedging potential of the target clauses. Thus, the findings and the issues raised in the paper may inform the classroom practice in the given non-native English academic context and generally contribute to better understanding of crosscultural academic writing.

\subsection{General characteristics of the English extraposed that-clauses and the Croatian declarative subject clauses}

Extraposition refers to a thematic variation which shifts the heavy or more complex part of the sentence in a post-predicate position and replaces it with the anticipatory pronoun it (Quirk \& Greenbaum, 1993; Herriman, 2000a). The extraposition of a clausal subject may be illustrated as follows:

a) That both accounts are correct is possible. (canonical sentence)

b) It is possible that both accounts are correct. (extraposition)

The derived extraposed sentence (b) consists of two elements: the matrix predicate (the main clause or It-clause) with the dummy it taking the subject position and the extraposed that-clause, which is essentially a postponed or extraposed subject. The subject of the extraposition, i.e. the dummy it, is non-referential and it semantically corresponds to the subject of the nominal that-clause (Biber et al., 1999; Huddleston \& Pullum, 2002). ${ }^{1}$ The extraposed that-clauses can be controlled by different types of matrix predicates, such as adjectives (e.g. It is likely), passive verb forms (e.g. It was believed), and nominal phrases (e.g. It is a pity.) (Biber et al., 1999). Importantly for the present study, previous research (Herriman, 2000a) has shown that certain matrix predicates occurring with particular types of extraposed clauses are associated with specific semantic meanings. Thus, the adjectives controlling thatclauses commonly denote epistemic modal meanings (e.g. It is possible that the respondents gave socially desirable responses.), while those followed by toinfinitive clauses typically signal dynamic meanings, such as potentiality (e.g. It is always possible to give socially desirable responses.).

According to Hewings \& Hewings (2002), the use of extraposition in English is motivated by both rhetorical and non-rhetorical reasons. The latter refers to the two principles that govern 'the presentation of the content of a clause,' the tendency to place the new information at or towards the end of the clause (the principle of end-focus), and the tendency to shift longer and more complex elements of a clause to its final position (the principle of endweight) (Quirk \& Greenbaum, 1993: 410). Rhetorically, the main function of

\footnotetext{
${ }^{1}$ In addition to that-clauses, matrix predicates can be followed by to-infinitive (e.g. It is possible to rent a car here.), wh-clause (e.g. It is not clear when the fire started.) and to a much lesser extent, ing-clauses (e.g. It's no use telling her to stop).
} 
the extraposition is to convey a writer's (or speaker's) attitude towards the content of the extraposed clause. For instance, the matrix predicate It is possible (that) may stand for a writer's personal judgment substituted by 'I think (that)' or a writer's report on some shared evaluation, meaning 'We/They think (that)'. Either way, by using the impersonal structure of the matrix itclause, writers (or speakers) can conceal the source of the evaluation, which allows them to make the essentially subjective opinions or judgments appear more objective and formal, which is particularly important in academic discourse (Herrimann, 2000a).

When it comes to Croatian, linguistic literature provides limited information on the congruent clause type. According to Silić \& Pranjković (2005), the declarative subject clauses ${ }^{2}$ are controlled by a specific type of antecedents denoting a certain mental, verbal, or emotional activity. ${ }^{3}$ The antecedents can be passivized or impersonal verb forms (e.g. Vjeruje se 'It is believed'), adverbials (e.g. Nužno je 'It is essential') or nominal expressions (e.g. Istina je 'It is true'). For example, in the sentence Moguće je da oni neće stići na vrijeme. 'It is possible that they will not arrive on time.', the matrix predicate containing the epistemic adverb 'moguće' conveys a writer's evaluation of the possibility that a state of affairs described in the dependent clause is true (Pranjković, 2001). In that sense, the semantic focus is in the complement clause, while the function of the matrix clause is its subjective modification (ibid.).

In sum, a brief characterization of English extraposition and the Croatian declarative subject clauses points to the congruence of both their structural and rhetorical properties, which broadly justifies the comparative analytical perspective adopted in the present study. Given the focus of the study, the following section outlines the role of extraposition in academic writing, particularly with respect to the English language.

\subsection{Extraposition in academic writing}

Large-scale corpus-based studies (Biber et al., 1999; Herriman, 2000b) have consistently documented the more frequent use of extraposition in academic register as compared to other registers, ${ }^{4}$ which may be accounted for by its

\footnotetext{
2 A declarative subject clause is a type of the explicit dependent clauses (Cro. eksplicitne zavisnosložene rečenice), defined as clauses in which a conjunction or another cohesive device substitutes an element of the main clause (Silić \& Pranjković, 2005).

3 Similarly to English extraposition, in addition to the conjunction $d a$, matrix predicates can be followed by conjunctions, e.g. kako 'how' or an interrogative pronoun, adverb or particle, such as kada 'when', kamo 'where', etc. (Pranjković, 2001).

${ }^{4}$ As a way of illustration, LGSWE findings report on 500 occurrences of extraposed clauses per mil. words (Biber et al., 1999).
} 
tendency to formal, objective, and impersonal framing of argumentation. According to Herriman (2000b), the preferred use of it-extraposed clauses in scientific writing indicates its main concern with negotiating new knowledge claims which require a careful use of linguistic means primarily associated with writers' mental processes. In addition to register variations, the importance of this construction for academic writers has been attested by a range of different research perspectives, such as professional vs. student writing (Hewings \& Hewings, 2001), native vs. non-native English writing (Larsson \& Kaatari, 2019), cross-linguistic academic writing (Diani, 2008), academic phraseology (Cortes, 2004), etc. Taking a broader scope on the use of that-complement clauses in professional and student writing, Hyland \& Tse (2005: 124) note that an evaluative that-clause, represents 'a powerful construction for expressing evaluative meanings'..., 'making the attitudinal meaning the starting point of the message and the perspective from which the content of the that-clause is interpreted'. As Herriman (2000b: 207) remarks, by dividing the evaluative stance from the evaluated content, the former is turned 'into an explicit statement of opinion', which can be further modified (e.g. It is very important to), providing writers with more evaluative possibilities than would be the case with the use of single lexical devices. In their study on anticipatory it-extraposed clauses in expert and undergraduate writing, Hewings \& Hewings (2001) identified four metadiscoursal functions of matrix predicates, including hedges (e.g. It is possible that), used to express various degrees of certainty, possibility, etc.; attitude markers (e.g. It is interesting to note that), denoting various writers' attitudes towards the content; emphatics (e.g. It is necessary to), expressing a writer's strong concern about something; and attribution (e.g. It has been argued+(no)reference), used to attribute a stance to an (un)named agent. The results showed the prevalence of hedging function in professional writing, whereas emphatics were more salient in student writing, suggesting that the use of the extraposed clauses may be driven by the specific rhetorical purposes of the genres.

The cross-cultural comparisons of English extraposition and equivalent structural patterns in other languages are rather scarce, particularly concerning academic writing. One exception is Diani's study (2008) which examined the use of It v-link ADJ to-/that-clause and their equivalents in Italian across two academic genres (research article openings and book reviews). The findings showed that in research article writing in both language groups, the given pattern is primarily used to express validity, i.e. epistemic judgments.

The matrix predicates of extraposed clauses have also been studied within the accounts on formulaic phraseological patterns in academic writing (Cortes, 2004), in particular lexical bundles. More specifically, it has been found that the lexical bundles controlling it-extraposed clauses are frequent- 
ly used as stance bundles (e.g. it is possible to/it is likely that), such as those concerned with signaling varying degrees of commitment writers decide to attach to the propositional content (Biber et al., 1999; Cortes, 2004; Hyland, 2008).

Descriptive accounts of the Croatian scientific style also point to the phraseological status of the matrix predicates of complement clauses, whose use reflects the predominantly impersonal and neutral characterization of academic writing (Silić, 2006).

\subsection{Present study}

Against the background outlined thus far, the main objective of the present study is to explore the use of extraposed that-clauses in the corpus of research articles (RA) in psychology published in English-medium journals and to compare it with the use of declarative subject clauses controlled by the conjunction $d a$ in the comparable corpus of articles published in the Croatian-medium journals. Specifically, it aims to investigate the following:

1. What is the frequency of the target clauses in two corpora?

2. How is the use of the target constructions distributed across the IMRAD structure of the articles?

3. Which matrix predicates are most frequent in each corpus and what are their hedging functions?

\section{Corpus and methodology}

\subsection{Corpus}

The present analysis is based on two comparable tailor-made corpora of the research articles in psychology written in Croatian and English (Varga, 2016). 5 The term comparable corpora refers to the corpora containing texts which share the same communicative purpose, yet written in distinct languages (Bowker \& Pearson, 2002). Each corpus consists of 30 articles published within a 10-year period (2005-2015) in the peer-reviewed Englishmedium and Croatian-medium journals in the selected sub-disciplines of psychology (see Appendix 1 for the full list of the journal titles). Due to the discrepancy of the sizes of two academic communities, the compilation of the corpora was somewhat constrained by the limited choice of psychology journals in Croatia, which governed the selection of the English-medium journals in terms of their broad subject domains. In order to make the com-

\footnotetext{
5 The present analysis is based on the corpus of journal articles used in the unpublished PhD dissertation (Varga, 2016), where a more detailed account of the criteria for the corpus compilation is provided.
} 
parison of data as meaningful as possible, efforts were made to select the journals, and accordingly the articles, that dealt with similar research topics, such as social psychology, emotion and motivation, personality, and other related topics. Another variable that merits attention concerns the nativeness of the English language used in the selected Engcor articles. Besides relying on the fact that all published articles must undergo a proofreading process, in line with the methodology of previous cross-cultural studies (Fløttum et al., 2006; Koutsantoni, 2006; but see Sanderson, 2008), two additional criteria were used in selecting the Engcor articles. The first author of the article, who was presumably its main writer, had to have an English-sounding name and surname, which admittedly does not warrant the nativeness of the language (Fløttum et al., 2006; Yang et al., 2015). However, though it is likely that English was not the mother tongue to all Engcor writers, the study is based on the premise that their number was rather low and could thus not contaminate the representativity of the corpus (Fløttum et al., 2006). Additionally, the first author had to be affiliated with a University Department of Psychology in a country where English is the official language. Therefore, the term English writer is used here to refer to the American, British, Canadian, and Australian speakers, affiliated with universities from the respective countries (Koutsantoni, 2006). The total word count (including only the textual body of the articles) ${ }^{6}$ of each corpus is shown in Table 1 . As the study aimed to explore the variation of the epistemic markers across the IMRAD rhetorical structure of research articles, further sub-corpora were compiled, each representing one of four RA rhetorical sections in the Crocor and the Engcor, respectively.

Table 1: Number of words across IMRAD in the Crocor and the Engcor

\begin{tabular}{ccc}
\hline & $\begin{array}{c}\text { ENGCOR } \\
\text { (English corpus) }\end{array}$ & $\begin{array}{c}\text { CROCOR } \\
\text { (Croatian corpus) }\end{array}$ \\
\hline No. of articles & 30 & 30 \\
\hline Total word count & 237,987 & 143,029 \\
\hline
\end{tabular}

\footnotetext{
${ }^{6}$ The corpus compilation excluded titles, tables, figures, references, footnotes, endnotes, appendices, texts under graphic material, information on the authors, and similar data. Also, following previous studies (e.g. Hyland, 1998), the abstracts were not included in the analysis, as they are considered to be a genre with its own rhetorical structure (ibid.).
} 


\subsection{Methodology}

The study combined corpus linguistic and qualitative methodology (Sanderson, 2008). The former involved the identification of the selected epistemic devices from the corpus by means of the computer software AntConc (Version 3.5.8), in particular the Concordancer tool. This was followed by the frequency analysis which aimed to reveal and compare the preferred choices of the target constructions across the IMRAD sections in two corpora. The qualitative analysis dealt with the contextual analysis of the pragmatics of matrix predicates, i.e. with the interpretation of their hedging functions across the IMRAD structure.

With respect to the English corpus, by using the search item it + predicate ('be'/'seem'/'appear'/a modal verb) + that-clause, all retrieved concordances were manually examined in order to ensure that only the matrix predicates of extraposed clauses performing hedging functions were included in the analysis. In Croatian, the search item was $d a-$, whereby only the instances with the impersonal forms of matrix predicates conveying epistemic evaluations were retrieved and subjected to further contextual analysis. This analytical procedure was performed for each separate RA section in Engcor and Crocor, respectively.

It is important to address several issues concerning the design of the present research. The focus of the study is narrowed to the specific type of complement clauses in both languages, since, as previously discussed, their matrix predicates are mainly used for conveying epistemic stance of various degrees of certainty that are expected to be associated with the pragmatic functions of hedging (Herriman, 2000a). However, the analysis of both corpora showed that there were a few instances in which a that- complement clause functioned as the object of a non-finite clause (Biber et al., 1999) which contained the matrix predicate conveying the epistemic meaning, e.g.

(1) It is logical to assume that improvements in learning environments...would enhance performance in the stereotyped domain. (Eng1)

The equivalent instances were also found in the Crocor, ${ }^{7}$ e.g.:

(2) ... pa je opravdano pretpostaviti da nema značajnu ulogu kao odrednica stava prema socijalnoj $i$ školskoj integraciji. (Cro1)

'...it is reasonable to assume that it does not have a significant role as a determinant of the attitude towards social and school integration.'

Given that the matrix predicates contained the lexical verbs whose semantics is associated with hypothetical rather than categorical state of affairs, such tokens were included in the frequency counts of the matrix predi-

\footnotetext{
7 In Croatian, these are instances of multiple-clause sentences (Cro. višestrukosložene rečenice) (Silić \& Pranković, 2005).
} 
cates containing lexical verbs and the subsequent analysis. On the other hand, the extraposed that-clauses used to express attitudinal evaluations which themselves were hedged were not included in the analysis given that their primary meaning expressed an attitude rather than an epistemic evaluation. For instance, in example (3), the writer primarily conveys surprise (i.e. it is surprising that), yet in a tentative manner, which is signaled by the use of double hedges (i.e. might and seem):

(3) It might seem surprising that people fall back on good habits when their will power is low. (Eng2)

Furthermore, reference should be made to the extraposed that-clauses with the matrix predicates 'it seems/appears', 8 which resemble ordinary extraposed constructions yet differ in lacking the nonextraposed alternatives (Herriman, 2000a; Huddleston \& Pullum, 2002), as in:

(4) It seems that the report is based on false data. *That the report is based on false data seems.

The status of 'it seems/appears that' constructions is not treated unanimously by English grammarians. Thus, Quirk et al. (1985: 1392) consider these constructions as cases of obligatory extraposition, while Huddleston and Pullum (2002: 960) use the term 'impersonal construction with it as subject', claiming that the content clause is an internal complement of the verb rather than the extraposed subject (for fuller discussion see Huddleston \& Pullum, ibid: 960-961). While the later argumentation bears validity, the grammatical status of these constructions is not central to the purposes of the present study that primarily deals with the specific pragmatic functions of the matrix predicates. As the preliminary corpus examination showed that these patterns are relatively common means of expressing hedged stance in the disciplinary writing under study and given their inclusion in the previous congruent studies (Biber et al., 1999; Hewings \& Hewings, 2002; but see Herriman, 2000a), they were included in the present analysis. Finally, the instances of the target complement clauses used to guide a reader through the text or in any other way express non-epistemic meaning were excluded from the investigation. The former was particularly common in the Croatian corpus, e.g.:

(5) Vidi se da postoje razne povezanosti ispitivanih varijabli ovisno o tipu dijabetesa. (Cro8)

'It can be seen that there are various correlations among studied variables depending on the type of diabetes.'

\footnotetext{
8 According to Biber et al. (1999: 436), seem and appear are treated as current copular verbs that 'identify attributes that are in continuing state of existence'. In academic prose, their use is mostly associated with denoting epistemic likelihood or more generally epistemic stance.
} 
By closely examining the corpora, the analysis yielded several lexicogrammatical categories of the matrix predicates denoting tentative stance towards the propositional content. The matrix predicates were divided into two main categories, viz. adjectival (Eng)/adverbial (Cro) and verbal, as indicated below:

\section{(1) Adjectival/Adverbial matrix predicates:}

- It is quite possible that liberals, on average, have more contact with gay men than do conservatives. (Eng3)

- Moguće je da stanje anksioznosti onemogućuje dijete u prepoznavanju pozitionih misli. (Cro2)

'It is possible that anxiety prohibits a child to recognize positive thoughts.'

\section{(2) Verbal matrix predicates:}

\section{a) Lexical verbs denoting mental processes: ${ }^{9}$}

- ..., it is hypothesized that high-N individuals may be particularly vulnerable to stress-related sleep disruption. (Eng4)

-...pretpostavljeno je da će generationa briga biti u najužoj vezi s altruističnom i instrumentalnom motivacijom za roditeljstvo. (Cro3)

'...it was hypothesized that generative concern would be closely associated to the altruistic and instrumental motivation for parenting.'

\section{b) Modal verbs:}

- Indeed, it may be that any situation involving skill acquisition is vulnerable to the negative effects of stereotype threat. (Eng1)

-...može se pretpostaviti da seksualna nevjera ima različite posljedice za restriktivne i nerestriktione sudionike. ${ }^{10}$ (Cro4)

'...it may be assumed that sexual infidelity has different consequences for restrictive and non-restrictive participants.'

\footnotetext{
9 The choice of the lexical verbs denoting mental processes was loosely based on Biber et al.'s (1999) taxonomy of mental verbs (e.g. assume, think, believe), Perkins' (1981) list of modal lexical verbs (e.g. assume, believe, think, understand) and Hyland's (1998) epistemic judgment verbs (e.g. predict, assume, speculate, indicate). All of these share a common property of denoting cognitive activities that are hypothetical rather than categorical in nature. With respect to Croatian, the choice of the lexical verbs followed those selected in English. The analysis showed predominance of two verbs, viz. smatrati 'consider' and pretpostaviti 'assume', which belong to the group of verbs denoting a mental activity (Pranjković, 2001). For a more extensive discussion of different taxonomies of lexical verbs performing hedging functions in academic writing, see Varga (2016).

${ }^{10}$ In the case of a matrix predicate with a modal verb, the infinitive is its obligatory complement.
} 
c) Impersonal construction with 'seem' or 'appear'/ Impersonal construction with činiti se 'seem':11

- It seems likely that the environment created by CMC encourages introverts and neurotic individuals to feel more at ease when conversing. (Eng5)

- Iako nisu utorđene razlike u zastupljenosti simptoma, čini se da postoje razlike u učincima nekih čimbenika. (Cro5)

'Though no differences in the presence of symptoms were found, it seems that the impact of certain factors is different.'

Following the given typology, each occurrence was classified into one of the four categories of matrix predicates. The total number of matrix predicates and their normalized frequencies per 1000 words (n/1000) were calculated at the section level for each corpus, along with their normalized frequencies per lexico-grammatical category.

\section{Results}

As seen in Table 2, the results point to the overall higher frequency of the target clauses in the Crocor, with 1.37 instances per 1000 words as compared to 0.43 instances reported in the Engcor. This suggests that the Croatian writers used the target construction as a more frequent means for expressing hedged stance than writers writing in English.

Table 2: Overall frequencies of the target clauses in the Engcor and the Crocor

\section{Raw frequencies}

Engcor

Crocor 103

196 $\mathrm{n} / \mathbf{1 0 0 0}$

With respect to the distribution of the target clauses across IMRAD sections (Figure 1), the results show similar tendencies in two corpora, conforming thus to the overall rhetorical purposes of the main RA sections. In other words, in both corpora the frequency of the target clauses is highest in the most argumentative sections (Hyland, 1998), namely the Discussion and the Introduction, while their frequencies are markedly lower in more description-focused sections (ibid.), especially the Methods in which they are almost non-existent. A low frequency of the target clauses in the Methods

\footnotetext{
${ }^{11}$ As the Crocor findings showed only one occurrence of the matrix predicate izgleda da 'it appears that', the analysis focused only on the use of the verb činiti se 'seem.'
} 
reflects its main rhetorical purpose, viz. the outline of the methodological procedures (ibid.), which normally does not require evaluations of the propositional content. Though the Results section is primarily dedicated to the report of the findings (Salager-Meyer, 1994), the present results show that the writers, especially those writing in Croatian, do not merely present the data in this section but also provide tentative comments towards the reported content. In Introduction, writers express evaluations towards theoretical and empirical background against which they situate their research, provide hypotheses for their work, etc., which justifies the use of various stance markers, including the target structures (Hyland, 1995). However, the highest density of the target clauses in the Discussion clearly shows that it in this section where writers intrude most in the text in order to interpret their research findings, discuss the implications, and address further research directions, etc., which makes the use of hedged statements in this part of a RA most salient (Salager-Meyer, 1994; Hyland, 1998).

When it comes to the distribution of the matrix predicates of the target clauses, the findings (Table 3) show both similarities and differences across two corpora. The major similarity refers to the fact that in both corpora, the adjectival/adverbial respective predicates are by far the most common predicates of the target clauses. Interestingly enough, in each corpus the same adjective/adverb showed the highest frequency of occurrences, viz. possible (i.e. it is possible that) and moguće (i.e. moguće je da), with the frequencies of 35 $(0,14 / 1000$ words) and 68 instances $(0,47 / 1000$ words), respectively. Moreover, it is the single most frequent matrix predicate of the target constructions in each corpus as a whole. With respect to the Engcor, this finding supports previous research on stance bundles (Cortes, 2004) that points to the saliency of 'it is possible that' bundle in disciplinary writing. A lack of empirical findings of the Croatian academic writing prohibits further claims on the equivalent status of 'moguć je $d a^{\prime}$ in Croatian, but given the previously mentioned theoretical account of the common phraseological expressions in the Croatian scientific style, it may be reasonably assumed that the given matrix predicate could have the status of a formulaic lexical bundle in the Croatian academic writing too.

The major discrepancy in the distribution of the matrix predicates in two corpora is related to the use of the lexical and modal verbs which are used notably less frequently in the Engcor. This finding might correspond to the overall less frequent use of mental verbs in academic register in English, including the function of reporting verbs (Biber et al., 1999). Indeed, previous studies show that RA writers report more frequently on other scholars' research (e.g. show, demonstrate), or verbal activities (e.g. suggest, discuss) rather than cognitive acts (Thomas \& Hawes, 1994; Hyland, 2004). As congruent empirical data on academic writing in Croatian is rather missing, the 
present findings cannot be integrated with previous research. Based on the present results, it can only be concluded that the Crocor writers make more frequent use of the verbal matrix predicates than their English counterparts in presenting their research and in taking hedged stance towards other scholars' claims and commonly-held disciplinary assumptions.

Figure 1: Distribution of the target clauses across IMRAD in the Engcor and the Crocor

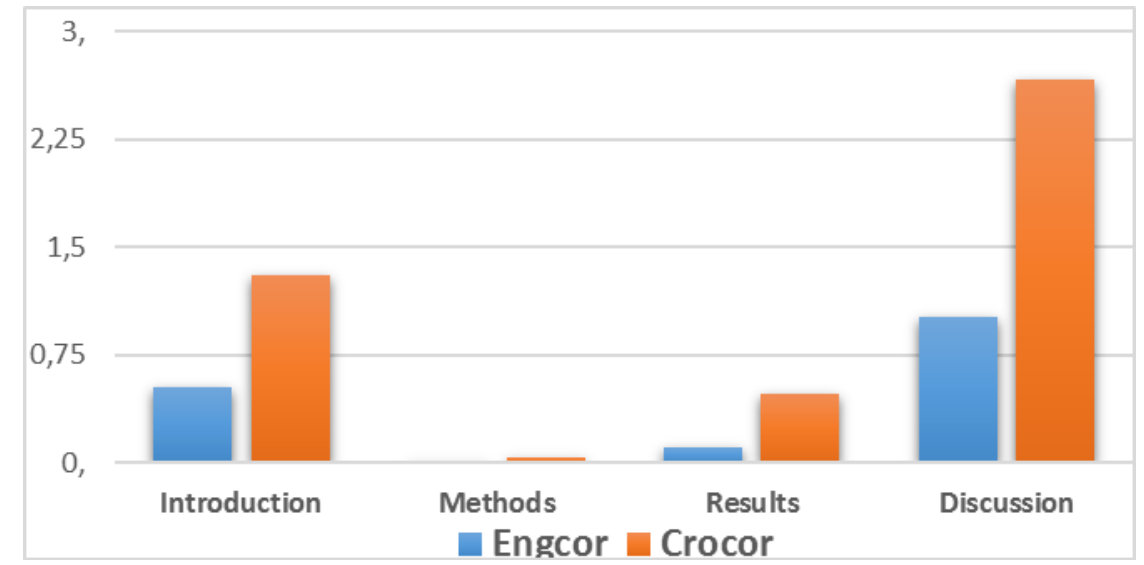

Table 3: Frequency of matrix predicates in the Engcor and the Crocor

Engcor

Crocor

Matrix predicate Raw frequency n/1000 Raw frequency n/1000

\begin{tabular}{|c|c|c|c|}
\hline $\begin{array}{l}\text { Adjetival/Adverbial } \\
\text { matrix predcates }\end{array}$ & 49 & 0.2 & 75 \\
\hline Lexical verbs & 20 & 0.08 & 42 \\
\hline Modal verbs & 12 & 0.05 & 49 \\
\hline $\begin{array}{l}\text { Impersonal construc- } \\
\text { tion with seem/ Im- } \\
\text { personal construction } \\
\text { with činiti se }\end{array}$ & 22 & 0.09 & 30 \\
\hline
\end{tabular}




\section{Discussion}

When it comes to the overall hedging functions of the matrix predicates in two corpora, their primary function can be viewed as a means of concealing the source of the (inter)personal epistemic judgment which may contribute to the objectivity and formality of writers' claims. In discussing the hedging functions of the target clauses, a general reference is made to Hyland's (1998) polypragmatic model of scientific hedging. The present findings indicate that the hedging potential of the target constructions in the Engcor and the Crocor can mainly be associated with the use of the writer-oriented hedges (ibid.). According to Hyland, their primary role is to diminish a writer's presence in the text and consequently their commitment to the propositions. As mentioned on several occasions in this paper, by using the impersonal forms of verbal matrix predicates of the target clauses, the explicit attribution for the claims is avoided. Consequently, responsibility for the latter is formally assigned to an unknown source, which may refer either solely to a writer and/or to any member of a disciplinary community. For example, in sentence:

(6) If true, it is logical to assume that improvements in learning environments and teaching techniques would enhance performance in the stereotyped domain. (Eng1)

by asserting the logical basis of the assumption, writers create an impression that the judgment is not solely theirs and that any other scholar, using the same logical principles, would reach the same assumption. In other words, by using the impersonal construction of the matrix predicate, an essentially subjective judgment is coded as a seemingly common one, which might be regarded as an attempt to protect oneself from a potentially mistaken judgment (Hyland, 1998).

The use of the impersonal matrix predicates of the target clauses in both corpora may also be concerned with a writer's decision to increase the precision of the claims, and accordingly their reliability. In Hyland's taxonomy of hedges, this pragmatic function is attributed to reliability hedges which indicate the extent to which the claims may be considered reliable and accurate within the existing (limited) scope of knowledge. For instance, in sentence (7), the writer is openly stating that the nature of evidence (or rather a lack of it) is such that a stronger claim cannot be made, suggesting only possible reasons for the discrepant results. In other words, the writer's choice of the matrix predicate signals that it is as furthest as the assumption can go if it is to be treated as trustworthy:

(7) Što je uzrok ovakvim nesukladnim rezultatima, ne može se sa sigurnošću utvrditi; moguće je da su oni odraz kulturalnih specifičnosti... (Cro6) 
'It is not possible to definitely establish what caused so inconsistent results; it is possible that they reflect cultural specifics...'

As the findings showed the highest frequency of the target clauses in the Introduction and Discussion sections in both corpora, due to the reasons of space, in what follows the focus will be given to the main hedging functions in those two sections only.

\subsection{English corpus}

When it comes to the specific use of the extraposed that-clauses in the Introduction, the findings show the highest frequency of lexical verbs and adjectives as the matrix predicates, while the remaining categories were used notably less frequently (see Appendix 2). Most often, writers used the given matrix predicates when introducing the present study or more specifically, in formulating their research hypotheses, yet without providing explicit attribution for the claim. However, as shown in example (8), despite the use of the impersonal construction, the contextual clues (i.e. the current study) make it clear that the source of the claim is a writer, hence the evaluation can be regarded as subjective:

(8) ... the current study examined the interactions of female dyads. Based on previous research, it is hypothesized that during a FtF interaction, extraversion will be negatively related to anxiety... (Eng5)

In other words, the writer is providing a personal stance but for some reasons is unwilling to express it overtly, as would be signaled by the use of the personal pronouns. This can be illustrated by the following example in which the writer alternates between personal and impersonal matrix predicates of the complement clauses:

(9) We also explored whether liberals and conservatives would differ in their awareness of these stereotypes. Although gender inversion stereotypes saturate mainstream culture (Blashill \& Powlishta, 2009; Kite E Deaux, 1986, 1987; McConaghy $\mathcal{E}$ Zamir, 1995), it is possible that liberals would report less knowledge of these stereotypes, and this could explain why they are less likely to use gender inversion cues. (Eng3)

When explaining the methodological steps of the research, the writer makes the authorial presence explicitly visible, which is signaled by the personal pronoun we. However, accounting for the possible reasons of a particular state of affairs may require greater caution in providing epistemic judgments, which might underlie the writer's decision to convey a personal evaluation impersonally, as indicated by the matrix predicate it is possible that.

Albeit less frequently, the target structures are also used to report on what might be termed as shared or intersubjective epistemic evaluations 
(Nuyts, 2001), presumably held by members of the discourse community, including the writer, as in:

(10) Depressive symptoms and inhibition of behaviors, although not academicrelated behaviors per se, may co-occur. It is often posited that increased depression leads to inhibited behaviors. (Eng6)

This function of the matrix predicates is particularly common in those segments of the Introduction where writers provide tentative comments in interpreting past research or literature data relevant for the scope of their own study.

Considering the use of the target clauses in the Discussion section in the Engcor, the findings show the overwhelming frequency of the adjectival matrix predicates, followed by the use of impersonal construction with seem/appear and a rather rare use of other verbal matrix predicates. The hedging functions of these matrix predicates are mostly associated with writers' cautious interpretations of the obtained findings, consolidations with previous research, or attempts to derive generalizations based on the present data. In that sense, they are mostly associated with indications of writers' assessments of the reliability of the assumptions, signaling their lack of commitment to the complete certainty of the claims, as in:

(11) Thus, it is possible that the shared variation evident in the present study may correspond to the ability to inhibit or prevent distracting information from entering working memory...(Eng7)

Despite the predominance of it is possible that, the findings show that writers used a greater variety of adjectives as matrix predicates (e.g. it is (un)likely, it is plausible, it is conceivable that, etc.), which may reflect the rhetorical purposes of the Discussion section. In other words, a wider range of adjectives suggests writers' greater need to convey different types and degrees of hedged stance towards their claims.

As already mentioned, the findings point to a relatively frequent use of the impersonal constructions with seem and to a lesser extent appear verbs ${ }^{12}$ functioning as matrix predicates. A particular feature of the former relates to the harmonic combinations ${ }^{13}$ with the adjectives likely or reasonable, e.g.:

(12) ..., it seems likely that the use of female confederates may have lessened participants' anxiety because they were conversing with someone of the same gender. (Eng5)

\footnotetext{
12 The LGSWE corpus findings (Biber et al., 1999) report on the predominant use of seem as opposed to appear in academic prose.

${ }_{13}$ The term HARMONIC refers to co-occurrences of modality devices with other items which already perform hedging functions, e.g. seem (Coates, 1983).
} 
In compound hedges of this type, the use of seem may be concerned with a writer's intention to increase the tentativeness of his or her claim, which is already signaled by the use of the epistemic adjective likely. In that way, hedged stance seems to be even more prominent as would be the case with the use of a single hedge only.

Finally, the use of modal verbs in this section mainly concerned the use of the matrix predicate it may be that, whose hedging status may be congruent to the more central predicate it is possible that, as shown in:

(13) Alternatively, it may be that as spouses collaborate and deliberately seek to reinforce each other's parenting, they become more similar over time. (Eng8)

\subsection{Croatian corpus}

When it comes to the use of the matrix predicates in the Introduction, the findings show the highest density of the lexical verbs in conjunction with modal verbs or without them, followed by the use of adverbials and impersonal construction with činiti se 'seem' (Appendix 2). The use of the lexical verbs is mostly concerned with presenting the background knowledge against which writers position their study. To that aim, writers in the present corpus mostly used the impersonal form of smatrati 'consider', particularly when referring to common disciplinary assumptions, e.g.:

(14) Općenito se smatra da je privrženost odrasle osobe umjereno stabilna, a da su promjene do kojih dolazi sustavne (Davila i Cobb, 2003). (Cro7)

'It is generally considered that attachment in adults is moderately stable, and that changes occur systematically.'

However, very often writers engage in interpretations of previous research, providing cautious assumptions about the reported content, yet leaving it unclear whether the epistemic judgment is strictly personal or a shared one. Thus, the choice of the impersonal construction of the matrix predicate might be regarded as a writer's strategic decision to formally disguise the overt source of the judgment and thus remain distant from the propositional content (Hyland, 2008; Yang et al., 2015), as in:

(15) Čini se da je emocionalna podrška važnija ženama nego muškarcima te da su kod žena socijalna podrška i zdravlje u većoj mjeri povezani (Schwarzer $i$ Leppin,1989.). (Cro8)

'It seems that emotional support is more important to women than men and that social support and health are more correlated in women.' 
Congruent to the use of the extraposition in the Engcor, the target clauses may also be used in coding strictly personal evaluations, such as expectations or assumptions the study is based on, e.g.:

(16) Na temelju se rezultata prethodnih istraživanja može pretpostaviti da će mladi sa sigurnim stilom privrženosti ujedno imati $i$ višu kvalitetu privrženosti roditeljima od mladih s nesigurnim stilovima privrženosti. (Cro9)

'Based on previous research findings, it can be assumed that the young people with secure attachment style would also have higher attachment quality to parents unlike those with anxious attachment style.'

These evaluations are usually expressed by means of the verb pretpostaviti 'assume' which often co-occurs with the impersonal form of the modal verb moći 'may'/'can'. The use of the modal in these cases may suggest that a writer feels reluctant to make a stronger commitment to the hypothesis (cf. Na temelju se rezultata prethodnih istraživanja pretpostavlja da...'Based on previous research findings, it is assumed that...'). In other words, the cooccurrence of the modal and the lexical verb may have a cumulative hedging effect. On the one hand, the assumption is made indirect through the choice of the impersonal construction of the matrix predicate, which by definition diminishes a writer's personal commitment to the claim. On the other hand, the modal verb further reduces its force, indicating additional caution in conveying the assumption. The co-occurrences of modal and lexical verbs were generally more salient in the Crocor, while in the Engcor they were rather rarely used.

The analysis of the Crocor data shows that adverbial matrix predicates as in Moguće je da stanje anksioznosti onemogućuje dijete u prepoznavanju pozitionih misli. (Cro2) 'It is possible that anxiety prohibits a child to recognize positive thoughts.' are also the most frequent matrix predicates in the Discussion as are in the Engcor. However, unlike English, Croatian writers used verbal matrix predicates significantly more frequently. The motivation for their use seems to be congruent with the use of the adjectival matrix predicates of the target clauses. That is, writers mostly use them when engaging in critical evaluations of their findings, or where the lack of more convincing evidence, gaps in knowledge, or awareness of various research limitations could not allow a stronger personal commitment to the claims.

When it comes to the distinct uses of the matrix predicates in two corpora, it might seem interesting to point out that unlike in the Engcor, compound hedges containing the impersonal form of the verb činiti se 'seem' accompanied by an adjective were not commonly employed in the Crocor, suggesting that it is not a conventional hedge in the present corpus. Indeed, only one instance (e.g. čini se vjerojatnim (adj.) da) was recorded in the Croa- 
tian data, which seems to be a direct translation of the English predicate 'it seems likely that'. However, the Crocor findings show that double hedging is often achieved by means of the harmonic combinations consisting of moći and a lexical verb denoting mental states (e.g. može se pretpostaviti da 'it can be assumed that'; moglo bi se zaključiti da 'it could be assumed that', etc.), whose equivalent occurrences were rarely used in the Engcor. This suggests that the given construction might be regarded as a language-specific hedging device in the disciplinary writing under study.

Finally, a finding that turned out to be specific to Croatian concerns the use of the matrix predicate može/moglo bi se reći da 'it can/could be said that' and its role in performing hedging functions. Though this matrix predicate was not included in the frequency analysis given that the lexical verb denotes a communicative rather than a cognitive state, it merits attention due to its relative frequency and the absence of its equivalent in the Engcor. As can be seen in the following example:

(17) ..., moglo bi se reći da ova strategija zahvaća prou fazu samoregulacije ponašanja (planiranje).... (Cro10)

'..., it could be said that this strategy relates to the first phase of behavioral self-regulation (planning)...'

the use of the matrix predicate is concerned with softening the force of the claim, which is further substantiated by the use of the conditional form of the modal. The writer presumably has sufficient grounds for the claim but avoids putting it forward directly. As a result, the claim introduced by the matrix predicate is made less assertive and possibly also less intrusive on readers. As already mentioned, the equivalent matrix predicate is nonexistent in the English corpus, which suggests that, at least in the disciplinary corpus under study, it does not seem to be an entrenched hedging expression. This and similar cross-linguistic differences may turn out to have useful implications for teaching purposes, as discussed in the closing section of the paper.

\section{Conclusion}

\subsection{Contrastive academic writing findings}

The study showed that the Croatian writers used the target clause more frequently than their English counterparts, which suggests its more entrenched status in the given disciplinary writing in Croatian. Both groups of writers used the target clauses most often in the Introduction and Discussion sections, in which the use of evaluative language is most salient. The target constructions were used for congruent purposes, i.e. to provide hedged statements that mainly concerned the outline of the research, particularly the 
formulation of the hypotheses, or to provide epistemic evaluations referring to the interpretations of the findings or their consolidation with previous work. In addition to the subjective evaluations, the target clauses were used to express common evaluations shared by members of the disciplinary community.

With respect to the use of the lexico-grammatical categories of matrix predicates, the comparison of the findings points to the saliency of adjectival/adverbial matrix predicates in the respective corpora, while the distribution of other categories showed considerable variations. The most notable difference relates to the use of modal verbs, which is the second most frequent category in the Crocor, and the least frequent one in the Engcor. The use of the modal verbs in conjunction with the lexical verbs denoting mental states can be viewed as one of the means Croatian writers use to increase the tentativeness of the claim. English writers achieve it by means of the harmonic combinations of the seem + adjective type, but their use is generally not as salient as the one with modal verbs in the Crocor.

Overall, the present findings might lead to the conclusion that Croatian disciplinary writers hedge their claims more than their English counterparts. A more comprehensive cross-cultural research on the use of hedges in the given disciplinary writing (Varga, 2016), however, revealed the opposite, i.e. writers writing in English used more hedging expressions than psychology writers writing in Croatian. The results of the current study only show that the target complement clauses are a more common means of expressing hedged stance in the Croatian corpus of research articles in psychology than in the comparable English corpus. The preference for the use of the target construction by Croatian writers seems to correspond to the predominantly impersonal characterization of the scientific writing style in Croatian. Indeed, the results of the above mentioned research showed a higher frequency of the finite forms of epistemic lexical verbs taking the human agents as subjects of that-complement clauses, e.g. We hypothesize that in English as compared to Croatian. This implies that English writers prefer aligning themselves personally with their epistemic judgments, showing unambiguously their epistemic positions, particularly with respect to announcing research hypotheses and predictions. By contrast, though the congruent use of the personal pronouns was not completely absent in the Crocor, Croatian writers showed preference to impersonal forms when expressing their epistemic judgments or reporting on those of other scholars.

The findings of the current study should be viewed against certain limitations concerning the research methodology. First, as the study was not based on a rigorous statistical analysis, the obtained differences in the frequencies of the data may not be statistically significant (Varga, 2016). Instead, the frequency analysis was conducted to explore and compare overall distribu- 
tional patterns of the use of the target clauses in the cross-cultural disciplinary writing. Another constraint refers to the corpus design. The research articles selected for the corpus dealt with subject areas from a few branches of psychology. In other words, the present findings show some characteristic features of research article writing in certain domains of psychology but not in psychology as a social science in general. Furthermore, it is likely that the analysis of other disciplinary discourses would reveal distinct patterns of the use of target constructions, so the findings cannot be taken as characteristic of the academic writing style in either of the languages under study.

Nevertheless, the study could be viewed as the first step in examining the pragmatics of complement clauses, particularly in the Croatian academic writing and as such, it may provide avenues for further research. The extraposed that-clauses and their equivalents in Croatian represent only one way of hedging the claims in academic writing and can be considered as a part of a broader repertoire of complement clauses used to achieve the same pragmatic effect. Therefore, in order to explore the full hedging potential of that-complement clauses, other matrix predicates should be included in the analysis too. Furthermore, as previous research has shown, that-clauses are used to convey various epistemic and attitudinal meanings. Likewise, Croatian linguistic literature reports that matrix predicates of the complement clauses can express different modal and attitudinal meanings, which, however, awaits empirical evidence. In that sense, further cross-cultural studies would be useful to explore the evaluative potential of the target clauses, which is particularly important for the rather understudied academic discourse in Croatian.

\subsection{Pedagogical implications}

The insights gained from the present and similar cross-linguistic analyses may also find their way in classroom practice in a non-native academic context. In other words, the research findings may inform syllabus design by drawing non-native scholars' attention to the observed similarities but particularly the differences in the preferred rhetorical choices in the disciplinary writing in English and Croatian. As Sanderson (2008) remarks, non-native scholars writing in English might best benefit from the language support programs tailored to address the distinctive patterns of the cross-cultural disciplinary language use. An example from the present study might refer to the preferred patterns concerning authorial visibility in making research hypotheses in English as compared to Croatian. Raising awareness and deepening our knowledge about the rhetorical conventions of cross-cultural writing is particularly important for non-native English scholars considering the ever-growing importance of publishing internationally and the role of English in that respect. 


\section{References}

Anthony, Laurence (2019). AntConc (Version 3.5.8) [Computer Software]. Tokyo, Japan: Waseda University. Available from https://www.laurenceanthony. net/software

Biber, Douglas, Stig Johansson, Geoffrey Leech, Susan Conrad, Edward Finegan (1999). Longman Grammar of Spoken and Written English. Essex: Pearson Education Limited.

Biber, Douglas (2006). Stance in spoken and written university registers. Journal of English for Academic Purposes 5: 97-116.

Bowker, Lynne, Jennifer Pearson (2002). Working with Specialized Language: A Practical Guide to Using Corpora. London; New York: Routledge.

Coates, Jennifer (1983). The Semantics of the Modal Auxiliaries. London: Croom Helm.

Cortes, Viviana (2004). Lexical bundles in published and student disciplinary writing: Examples from history and biology. English for Specific Purposes 23: 397423.

Diani, Giuliana (2008). Introductory 'it' patterns in English and Italian academic writing: A cross-generic and cross-cultural analysis. L'Analisi Linguistica $e$ Letteraria 16: 343-355.

Fløttum, Kjersti, Trine Dahl, Torodd Kinn (2006). Academic Voices: Across Languages and Disciplines. Amsterdam: John Benjamins.

Herriman, Jennifer (2000a). Extraposition in English: A study of the interaction between the matrix predicate and the type of extraposed clause. English Studies 81(6): 582-599.

Herriman, Jennifer (2000b). The functions of extraposition in English texts. Functions of Language 7(2): 203-230.

Hewings, Ann, Martin Hewings (2001). Anticipatory 'it' in academic writing: an indicator of disciplinary difference and developing disciplinary knowledge. Hewings, Martin, ed. Academic Writing in Context: Implications and Applications. London: Continuum, 199-214.

Hewings, Martin, Ann Hewings (2002). "It is interesting to note that...": A comparative study of anticipatory 'it' in student and published writing. English for Specific Purposes 21: 367-383.

Huddleston, Rodney, Geoffrey K. Pullum (2002). The Cambridge Grammar of the English Language. Cambridge, UK; New York: Cambridge University Press.

Hyland, K. (1995). The author in the text: Hedging scientific writing. Hong Kong Papers in Linguistics and Language Teaching 18: 33-42.

Hyland, Ken (1998). Hedging in Scientific Research Articles. Amsterdam: John Benjamins Publishing Company.

Hyland, Ken (2004). Disciplinary Discourses: Social Interactions in Academic Writing. University of Michigan Press.

Hyland, Ken (2005). Metadiscourse: Exploring Interaction in Writing. London, New York: Continuum.

Hyland, Ken, Polly Tse (2005). Hooking the reader: A corpus study of evaluative that in abstracts. English for Specific Purposes 24: 123-139.

Hyland, Ken (2008). As can be seen: Lexical bundles and disciplinary variation. English for Specific Purposes 27: 4-21. 
Koutsantoni, Dimitra (2006). Rhetorical strategies in engineering research articles and research theses: Advanced academic literacy and relations of power. Journal of English for Academic Purposes 5: 19-36.

Larsson, Tove, Henrik, Kaatari (2019). Extraposition in learner and expert writing: Exploring (in)formality and the impact of register. International Journal of Learner Corpus Research 5(1): 33-62.

Nuyts, Jan (2001). Epistemic Modality, Language, and Conceptualization: A CognitivePragmatic Perspective. Amsterdam/Philadelphia: John Benjamins.

Perkins, R. Michael (1983). Modal Expressions in English. London: Frances Pinter.

Pranjković, Ivo (2001). Kompletivne rečenice. Šikić, Anita, ed. Druga hrvatska skladnja: sintaktičke rasprave. Zagreb: Hrvatska sveučilišna naklada, 64-68.

Quirk, Randolph, Sidney Greenbaum, Geoffrey Leech, Jan Svartvik (1985). A Comprehensive Grammar of the English Language. London: Longman.

Quirk, Randolph, Jan Greenbaum (1993). A University Grammar of English. Essex: Longman.

Salager-Meyer, Françoise (1994). Hedges and textual communicative function in medical English written discourse. English for Specific Purposes 13 (2): 149-171.

Sanderson, Tamsin (2008). Corpus, Culture, Discourse. Tubingen: G. Narr.

Silić, Josip (2006). Funkcionalni stilovi hrvatskoga jezika. Zagreb: Disput.

Silić, Josip (2008). Tekst i funkcionalni stilovi. Anagram. Retrieved from http:// www.hrvatskiplus.org/article.php?id=1834\&naslov=tekst-i-funkcionalni-stilovi.pdf [17 November 2015]

Silić, Josip, Ivo, Pranjković (2005). Gramatika hrvatskoga jezika: za gimnazije i visoka učilišta. Zagreb: Školska knjiga.

Thomas, Sarah, Thomas P. Hawes (1994). Reporting verbs in medical journal articles. English for Specific Purposes 13(2): 129-148.

Varga, Mirna (2016). Epistemic Modality in Academic Discourse in the Croatian and English Language. (Unpublished doctoral dissertation) Osijek: Filozofski fakultet Osijek.

Yang, An, Shu-yuan Zheng, Guang-chun Ge. (2015). Epistemic modality in Englishmedium medical research articles: A systemic functional perspective. English for Specific Purposes 38: 1-10.

\section{List of abbreviations:}

\section{LGSWE Longman grammar of spoken and written English}

(Eng1) Rydell, Robert J, Michael T Rydell, Kathryn L Boucher (2010). The effect of negative performance stereotypes on learning. Journal of Personality and Social Psychology 99: 883-896. doi: 10.1037/a0021139

(Eng2) Neal, David T, Wendy Wood, Aimee Drolet (2013). How do people adhere to goals when willpower is low? The profits (and pitfalls) of strong habits. Journal of Personality and Social Psychology 104: 959-975. doi: 10.1037/a0032626

(Eng3) Stern, Chadly, Tessa V West, John Jost, Nicholas O Rule (2013). The politics of gaydar: Ideological differences in the use of gendered cues in categorizing sexual 
orientation. Journal of Personality and Social Psychology 104: 520-541. doi: 10.1037/a0031187

(Eng4) Williams, Paula G, Tammy L Moroz (2009). Personality vulnerability to stressrelated sleep disruption: Pathways to adverse mental and physical health outcomes. Personality and Individual Differences 46: 598-603. doi: 10.1016/j.paid.2008.12.017

(Eng5) Rice, Lindsay, Patrik M Markey (2009). The role of extraversion and neuroticism in influencing anxiety following computer-mediated interactions. Personality and Individual Differences 46: 35-39. doi: 10.1016/j.paid.2008.08.022

(Eng6) Yibing, Li, Richard M Lerner (2011). Trajectories of school engagement during adolescence: Implications for grades, depression, delinquency, and substance use. Developmental Psychology 47: 233-247. doi: 10.1037/a0021307

(Eng7) Bayliss, Donna M, Christopher Jarrold, Alan D Baddeley, Deborah M Gunn, Eleanor Leigh (2005). Mapping the developmental constraints on working memory span performance. Developmental Psychology 41: 579-597. doi: 10.1037/00121649.41.4.579

(Eng8) Schofield, Thomas J, Rand D Conger, Monica J Martin, Gary D Stockdale, Katherine J Conger, Keith F Widaman (2009). Reciprocity in parenting of adolescents within the context of marital negativity. Developmental Psychology 45: 1708-1722. doi: 10.1037/a0016353

(Cro1) Čorkalo Biruški, Dinka, Dean Ajduković (2012). Što određuje međuetničke stavove adolescenata u podijeljenoj zajednici? Društvena istraživanja 4 118: 901-921. doi: $10.5559 /$ di.21.4.05

(Cro2) Živčić-Bečirević, Ivanka, Željko Rački (2006). Uloga automatskih misli, navika učenja i ispitne anksioznosti u objašnjenju školskog uspjeha i zadovoljstva učenika. Društvena istraživanja 6 86: 987-1004.

(Cro3) Tucak Junaković, Ivana, Iva Ahmeti (2012). Motivacija za roditeljstvo i briga za mlađe naraštaje u mlađih i sredovječnih roditelja. Društvena istraživanja 2 116: 363382. doi:10.5559/di.21.2.04

(Cro4) Pavela, Irena, Benjamin Banai, Nataša Šimić (2013). Reproduktivne strategije i ljubomora muškaraca i žena. Društvena istraživanja 3: 517-535. doi: 10.5559/di.22.3.07

(Cro5) Kurtović, Ana, Ivana Marčinko (2011). Spolne razlike u atribucijama negativnih i pozitivnih događaja te depresivnim simptomima. Psihologijske teme 201 : $1-25$.

(Cro6) Martinac Dorčić, Tamara, Barbara Kalebić Maglica (2009). Povezanost osobina ličnosti s bračnom kvalitetom i izraženošću psihičkih simptoma kod bračnih partnera. Psihologijske teme 18 1: 75-97.

(Cro7) Smojver-Ažić, Sanja, Ines Jakovčić (2006). Percepcija prošlih odnosa i privrženost adolescenata i njihovih majki. Psihologijske teme 15 1: 59-80.

(Cro8) Petričić, Antica, Anita Vulić-Prtorić (2009). Neki prediktori suočavanja s dijabetesom tipa 1 i tipa 2. Društvena istraživanja 1-2 99-100: 47-65.

(Cro9) Ručević, Silvija, Ivana Mihalj (2013). Privrženost u adolescenciji - odnos kvalitete, stilova i dimenzija privrženosti: Usporedba djevojaka i mladića. Psihologijske teme 22 1: 69-91. 
(Cro10) Mujagić, Amela, Vesna Buško (2012). Upravljanje učenjem: Konstrukt samoregulacije i struktura njegovih komponenata. Suvremena psihologija 15 2: 157-175.

\section{Author's address:}

Mirna Varga

University of Josip Juraj Strossmayer, Osijek

Faculty of Humanities and Social Sciences Osijek

L. Jägera 9, 31000 Osijek, Croatia

e-mail: mvarga@ffos.hr

Received: September 30, 2020

Accepted for publication: December 1, 2020 


\section{Appendix 1}

\section{List of English journals}

1. Journal of Personality and Social Psychology

2. Developmental Psychology

3. Personality and Individual Differences

\section{List of Croatian journals}

1. Psihologijske teme

2. Suvremena psihologija

3. Društvena istraživanja 


\section{Appendix 2}

Table 1: Frequency counts (n/1000) of English matrix predicates in IMRAD

$$
\begin{array}{llll}
\text { I } & \mathbf{M} & \mathbf{R} & \mathbf{D}
\end{array}
$$

Matrix predicate $\quad \mathrm{n} / \mathbf{1 0 0 0} \quad \mathrm{n} / \mathbf{1 0 0 0} \quad \mathrm{n} / \mathbf{1 0 0 0} \quad \mathrm{n} / \mathbf{1 0 0 0}$

$\begin{array}{lllll}\text { Adjectives } & 0.18 & - & 0.01 & 0.6\end{array}$

$\begin{array}{lllll}\text { Lexical verbs } & 0.23 & - & 0.03 & 0.05\end{array}$

$\begin{array}{lllll}\text { Modal verbs } & 0.06 & - & 0.03 & 0.1\end{array}$

Impersonal construc-

$\begin{array}{lllll}\text { tion with seem } & 0.04 & 0,02 & 0.03 & 0.26\end{array}$

Table 2: Frequency counts (n/1000) of Croatian matrix predicates in IMRAD

$\begin{array}{lcccc} & \mathbf{I} & \mathbf{M} & \mathbf{R} & \mathbf{D} \\ \text { Matrix predicate } & \mathrm{n} / \mathbf{1 0 0 0} & \mathrm{n} / \mathbf{1 0 0 0} & \mathbf{n} / \mathbf{1 0 0 0} & \mathbf{n} / \mathbf{1 0 0 0} \\ \text { Adverbs } & 0.23 & 0.04 & - & 1.40 \\ \text { Lexical verbs } & 0.50 & - & 0.06 & 0.37 \\ \begin{array}{l}\text { Modal verbs } \\ \begin{array}{l}\text { Impersonal construc- } \\ \text { tion with činiti se }\end{array}\end{array} & 0.41 & - & 0.37 & 0.42 \\ \end{array}$

